\title{
Keeping an Eye on the Screen: Application Accessibility for Learning Objects for Blind and Limited Vision Students
}

\author{
Cristiani de Oliveira Dias and Liliana Maria Passerino \\ Interdisciplinary Centre for New Technologies Education \\ [Centro Interdisciplinar de Novas Tecnologias na Educação \\ - CINTED], Federal University of Rio Grande do Sul, \\ Porto Alegre - RS, Brazil \\ cristianideoliveiradias@gmail.com; liliana@cinted.ufrgs.br \\ João Carlos Gluz \\ Interdisciplinary Program in Applied Computer Science \\ (PIPCA), Vale do Rio dos Sinos University (UNISINOS), \\ São Leopoldo - RS, Brasil \\ jcgluz@unisinos.br
}

\begin{abstract}
A new profile emerges with the Web 2.0. It has evolved from users as mere information receivers to users as creators and content developers. In this new profile users may generate and produce material to later share it with classmates and teachers through the Internet. Nowadays, one of the main challenges teachers face is how to follow students through the digital world and beyond, while making use of these digital resources in order to make classes approachable so that students feel motivated to learn. Therefore we understand that teachers can interact with students by developing richer digital educational material that is able to accommodate all students, including those with special educational requirements. This paper's main goal is to analyze Learning Objects with a focus on accessibility issues and to recommend applications for the construction of accessible Learning Objects for individuals with special educational requirements.
\end{abstract}

Keywords: Inclusive Education, Learning Objects, Accessibility, Visual Impairment, Assistive Technology.

\section{Introduction}

Material published as part of this publication, either on-line or in print, is copyrighted by the Informing Science Institute. Permission to make digital or paper copy of part or all of these works for personal or classroom use is granted without fee provided that the copies are not made or distributed for profit or commercial advantage AND that copies 1) bear this notice in full and 2) give the full citation on the first page. It is permissible to abstract these works so long as credit is given. To copy in all other cases or to republish or to post on a server or to redistribute to lists requires specific permission and payment of a fee. Contact HPublisher@InformingScience.orgH to request redistribution permission.
We live in society where it is expected that all people may participate in all sorts of social environments. At the same time, this society exalts an inclusive education in which every single person should have the opportunities for choice and self-determination (Mittler, 2003). According to Mittler, an inclusive education does not imply placing all children in school, but transforming the 
schools in order to become more responsive to all student needs and to aid teachers into accepting the responsibility for their students' learning. Students have evolved from mere information receivers to creators and content developers in which they may generate and produce material to later share it with classmates and teachers by means of the Internet. One of the main challenges for a teacher nowadays is how to follow students through a digital world and go beyond that by making use of these resources in order to make classes approachable so that students feel motivated to learn. Therefore we comprehend that teachers can be part of this interaction with the student by developing richer digital educational material that is able to include all students. The diversity in media is able to favor the inclusion of students with special educational needs and the same goes for the adaptation of such digital educational material.

The main goal of this paper is to analyze Learning Objects (LO) (Wiley, 2001), with a focus on accessibility issues, and recommend applications for the construction of accessible Learning Objects to individuals with special educational requirements.

The interest in this research came from a study on Learning Objects and its application in public schools, which received the incentive of the Brazilian Federal Government for the development of such educational material as an alternative approach for educational technology (RIVED/SEED, 2008).

Among several programs that promote the development of LO, the Interactive Web of Virtual Education (in Portuguese RIVED - Rede Interativa Virtual de Educação) is a Brazilian program that makes use of digital pedagogical resources in order to aid the development of students' reasoning abilities and critical thinking. RIVED will form a virtual and interactive educational web, which associates the potential of computer science to new pedagogical approaches. Project RIVED is a program of the Distance Education Secretary (SED) of the Brazilian Ministry of Education (MEC), which is the Ministry's department for distance learning in Brazil. The project aims to produce digital pedagogical content in the form of Learning Objects. Project RIVED started in 1997, when, in agreement with the United States, it began the development of technological material for education. The staff of development was formed by several educators from Brazil, Peru, and Venezuela, and worked together until 2003, producing 120 objects for a variety of high school disciplines.

The distribution of the educational material produced by Universities and other learning institutions reaches a great number of public schools. The allocation is carried out by means of electronic formats distributed by the Ministry of Education in each state in Brazil. In 2004 the responsibilities of development were transferred to several Universities in Brazil, transforming the project into a "Virtual Factory". This transference caused the growth in production of objects able not only to serve higher education, but also basic and technical education. All objects developed were distributed to public schools, allowing students and teachers to make use of them in class.

Other projects also evolved in order to promote LO's use and production. As an example, there is the International Database of Educational Objects (in Portuguese BIOE - Banco Internacional de Objetos Educacionais) from Brazil. According to the Brazilian Ministry of Education (2009), this International Database of Educational Objects will become a portal with the intent to assist teachers. The database makes available many free educational resources through several kind of media and different languages (audio, video, animation/simulation, hypertext, educational software), ranging from basic education up to higher education in most knowledge areas.

Among other actions that were implemented, one may encounter the Teacher's Portal (http://portaldoprofessor.mec.gov.br), where the teacher must register in order to create and share resources and material with colleagues, prepare lessons, and access institutions or school sites. Another continuous formation program is the Medias in Education project, created with the intent to instruct professionals who learn how to work with media resources so that they can develop 
didactic material in the classroom and thus become multipliers. The Learning Objects are built based on agents in order to improve flexibility, adaptability, and interactivity within educational environments. In addition there is creation of a new Brazilian metadata standard for Learning Objects, called OBAA (Vicari et al., 2010), that may operate in diverse platforms like the Web or even mobile platforms or Digital TV.

Parallel to these programs that motivate the production of didactic material, the Brazilian Federal Government has been promoting the school inclusion process since 2003 (SEESP, 2003). On the educational side, this is regarded as an important process aligned with the principle "educate for diversity". Keeping this principle in mind, it is possible to perceive that we are face-to-face with a new paradigm that can be called the paradigm of inclusion.

Within an inclusive paradigmatic view, there is no room for considering the educational process as being separate and segregated. In this case, the teacher needs to plan, select, and build the didactic material that will provide a base for the knowledge appropriation process of all students. However, the development of inclusive didactic materials should meet accessibility criteria. As a consequence, such criteria should also be used in the construction of learning objects.

Besides the social concepts of accessibility and inclusion, there are many other reasons why to invest in the accessibility of a product, including, for instance, legal and economical reasons. By market logic, every enterprise that cares to expand business is in need of contemplating the biggest number of people possible. Making its product reachable to all sorts of people is a policy that is in search for market expansion and greater profits. In legal terms, the concept of accessibility that emerged in Brazil was already making a reference through communication. As to the law decree \#3.298 of 1999, the accessibility in the federal public administration in Brazil defined it as an achievable condition of approach of utilization with assurance and autonomy of spaces, urban furnishings and equipment of the facilities and sporting equipment, the edification, transportation, and the systems and means of communication (Brazil, 1999).

Considering what has been discussed, it is possible to perceive that public policy promoting the development of didactic material, as well as the enrollment of individuals with special needs in regular school, requires a better articulation so that investment results benefits everyone. One great challenge is how to develop LO that can be accessible to the blind and those with limited eyesight and that respects the principle of diversity and inclusion without becoming a resource for only few students. It should be so that teachers may make use of it in different manners with the entire class.

For the development of Learning Objects, there are standards that assure the portability of objects in different spaces. However, what has been observed is that these standards are more concerned with technological aspects, relegating pedagogical aspects to a second level.

Generally the construction of content on learning objects is the focus of development. However, when it comes to content, the quality is not the only variable that should be regarded in this public policy. Considering that content constitutes a doorway to the educative process we need to think of the access and comprehension of information in a mode to serve diversity in the classroom.

Considering these questions, several researches were carried out in the context of the Learning Object Supported by Agents (OBAA) project (Vicari et al., 2010), studying the Learning Objects that are available in classrooms through portals such as RIVED. This showed us that practically all of these objects do not conform to the minimum accessibility recommendations (Behar, Passerino, Dias, Fronzi, \& Silva, 2009). The present research aims to deliberate on how the adaptation process of Learning Objects can attend accessibility criteria and to propose a methodology for the adaptation of accessible LO. The presentation of the methodology takes into account its implications in terms of software engineering, and also the expected educational results due to its 
In the paradigm of inclusive education, all technological resources used in the learning process, including Learning Objects (Wiley, 2001), also need to be accessible. In this case, LO are considered as small reusable digital components to be used in education.

The concept of reusability is similar to the reutilization of objects in object-oriented programming where the entire object's code or part of it can be used in the development or adaptation of another program. Depending on the target public that will use this object, it may be remodeled to attend its needs (Takahashi, 1990).

Present research started looking for accessible Learning Objects but found only a few objects, which were not actually focused on the accessibility concepts previously mentioned. We believe that for Learning Objects to be accessible by those with special needs, they must be constructed with accessibility needs in mind from the start. This concern is not recent. Several research projects approach this accessibility issue showing the importance of adapting material to different student necessities (Sonza, 2008). However, most of the time these proposals are about how to readapt material to a certain requirement or limitation. There is, for example, the educational material developed by the Technological Institute of Bento Gonçalves (in Portuguese Cefet-BG) at the following site: http://www.bento.ifrs.edu.br/.

In short, materials that claim to be accessible are actually "new" versions that are differentiated from original educational material and that somehow exclude the handicapped student by not permitting interaction of him with the same material. Therefore, the "adapted" material deprives the student from having access to the full information.

\section{Learning Objects Adaptation: First Approach}

In order to achieve our research goals it was necessary to define a methodology for the adaptation of LO into accessible LO, and validate this methodology with an existing LO, through the application of the resulting accessible LO with students with special needs. The accessibility adaptation process was centered on blind students. A qualitative research approach was chosen as the basis of the methodology, with a focus on the analysis of standards for the definition of requirements, and with the validation of technological development through field research. The four stages of the methodology are presented below.

\section{Stage 1: Choice of Learning Objects}

This stage aims to show that Web pages accessibility criteria can be also applied to LO. To do so, a case study with a particular object was developed. The selected object is a game entitled "Banca do Quincas" (Quinca's Shop) that won a prize during the 2007 RIVED's Award contest developed by the University of Salvador (UNIFACS). The main characteristic of this game is to be a simulation style open LO where it is possible to manage a shop that sells organic products (for more information see Santanche (2008) at http://logames.sourceforge.net). The choice also was influence due to a partnership between research groups at the Federal University of Rio Grande do Sul (UFRGS) and the University of Salvador.

\section{Stage 2: Initial Accessibility Evaluation of Learning Objects}

In this methodology the validation of Learning Objects is continuous, forming a part of the entire process since the analysis up to the implementation of the object, following Granollers' (2004) User-Centered Design (UCD) methodology.

In order to evaluate the accessibility of this object before the restructuring process, an initial test was conducted with an individual with low vision (loss of central vision, while retaining peripheral vision). The evaluation resulted as non-accessible. 


\section{Stage 3: Re-engineering Process of Learning Objects}

According to Chilkofsky and Cross (1990), re-engineering can be compared to (a) direct engineering: a traditional process starting from high level abstractions and logical projects that come to the implementation of the system; (b) reverse engineering that creates the representations of a system in another form or in a higher level of abstraction; (c) restructuring that stands for the transformation of a representation into another in the same level of abstraction, preserving the external behavior of the system. Re-engineering is composed by reverse engineering and also by direct engineering or by restructuring. In contrast with restructuring, re-engineering can involve modifications in functionality or by techniques of implementation. According to Coleman (1996), the intention to re-engineer a chosen object is to create new functionalities from existing ones by modifying the source-code of the object. Following the author's ideas, we chose the (b) scenario in which an addition in the implementation of the system took place without affecting its functionality.

In our case, the implementation consisted of a communication bridge called Java Access Bridge which allows the communication among screen reader software with the learning object. Initially the selected LO was used with blind and low-vision students, without the adaptation, to identify the weak points and limitations of this LO, in respect to accessibility issues. This experimentation facilitated the subsequent inclusion of accessibility API that incorporated other accessibility features to the LO.

Besides the accessibility API, we also used the Java Accessibility Utility, which is formed by classes intended to help the development of assistive technologies able to access programs working on the virtual Java, and understanding API accessibility (Sun, 2009a. 2009b. 2009c).

We assumed that Learning Objects should be built in the perspective of object oriented software development. Thus, we have opted to develop the software using the Fusion method (Coleman, 1996). Fusion is an object oriented software development process, which supplies all resources for analysis, project, and implementation. The process is divided into:

Analysis phase: this is the phase where the expected behavior of the system is defined. In this phase, we made several studies about the objects' original source-code, and UML diagram, built by the initial development team.

Project phase: during this phase we created an ER Diagram for the object (Figure 1), in order to verify which are the functionalities of the object and how is the interaction processes of the object with the user. The re-engineering process of the object showed that Table element (see Figure 1) makes all interactions with users. In the resulting adapted LO, this Table element, was reconstructed as a Web form, now accessible to screen reader software. 


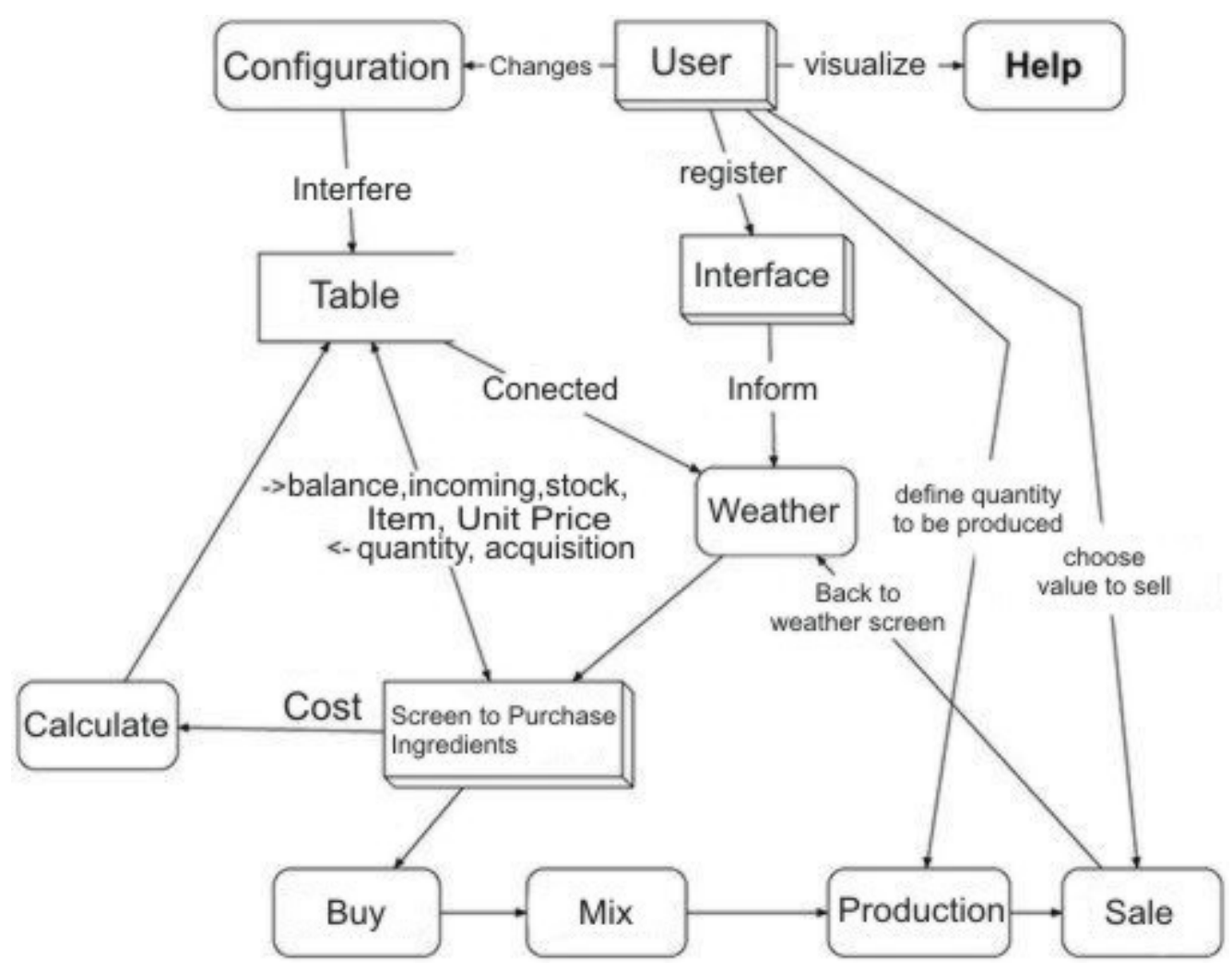

Figure 1 - Relationship-Entity Diagram of the LO Quincas Shop

The object's metadata structure was also extended to support the OBAA accessibility metadata (Vicari et al., 2010) in order to represent the accessibility information added to the object (Table 2).

Table 2: Part of the meta-data developed in the OBAA project (Vicari et al., 2010).

\begin{tabular}{|l|l|l|l|l|}
\hline Name & Description & Size & Values & Origin \\
\hline 10. Accessibility & $\begin{array}{l}\text { Accessibility is the ability of the } \\
\text { learning environment to adapt to } \\
\text { the needs of each user/student }\end{array}$ & 1 & - & OBAA \\
\hline 10.1 Has Visual & $\begin{array}{l}\text { Indication of the existence of LO if } \\
\text { the same presents content with vis- } \\
\text { ual information }\end{array}$ & 1 & true, false & OBAA \\
\hline 10.2 Has Auditory & $\begin{array}{l}\text { Indication of the existence of LO if } \\
\text { the same presents content with } \\
\text { auditory information }\end{array}$ & 1 & true, false & OBAA \\
\hline
\end{tabular}

Implementation phase: in this phase was implemented the Java Access Bridge communication connection for the object. 


\section{Stage 4: Validation of Adapted Learning Objects}

In the methodology we are following, we consider that the user is both part of the creation and the evaluation process of the LO. Users tested several versions of the adapted LO, during the development phases of this object, and after the development. The combination of all these tests form the validation process of the adapted object.

Table 3 presents a synthesis of the validation process, including the initial evaluation performed in Stage 2.

We understand that validating the adaptation process with only one single individual is not enough. These tests were conducted with 5 individuals with different visual problems, including total blindness and two types of low vision (subnormal vision and only peripheral vision). The individuals also have different technical skills, ranging from users with no knowledge about computers, to users with intermediate knowledge about how to use computers. Two users are primary school students, one of them is a secondary school student, and the other two users are primary school teachers, which work with blind and low vision students in a inclusive school.

All tests were conducted in a notebook which, besides the learning object, contained several screen reader software programs. The screen readers used in the tests were DOSVOX (Borges, 2006), ORCA (2009), and NVDA. These readers were selected because they are free, they are already known by users, and they are used in schools. The test sessions were video recorded; the duration of these sessions depended on the user's interest, and knowledge. The observation protocol aimed to verify the accessibility level of the object, including all of its contents. This protocol was not intended to check the user competence.

Table 3: LO validation with the user.

\begin{tabular}{|l|l|l|l|}
\hline Individual & Validation stage & $\begin{array}{l}\text { Previous } \\
\text { knowledge }\end{array}$ & $\begin{array}{l}\text { Really accessible? (user's point of } \\
\text { view) }\end{array}$ \\
\hline $\begin{array}{l}\text { A1 (only } \\
\text { peripheral } \\
\text { vision) }\end{array}$ & $\begin{array}{l}\text { Initial evaluation, before the ad- } \\
\text { aptation. LO with no adaptation } \\
\text { resource, initial process. }\end{array}$ & Yes & $\begin{array}{l}\text { No because the Jaws reading screen } \\
\text { could not read the application in Java. } \\
\text { This evaluation was done at the beginning } \\
\text { of the research. }\end{array}$ \\
\hline A2 (blind) & $\begin{array}{l}\text { Validation stage during the middle } \\
\text { of the adaptation process }\end{array}$ & Yes & $\begin{array}{l}\text { Not very accessible as audio was on a } \\
\text { high level. }\end{array}$ \\
\hline S (blind) & $\begin{array}{l}\text { Last stage, validation with } \\
\text { individuals. }\end{array}$ & Yes & $\begin{array}{l}\text { Accessible. Capable of use in class with } \\
\text { blind students. }\end{array}$ \\
\hline $\begin{array}{l}\text { A (subnor- } \\
\text { mal vision) }\end{array}$ & $\begin{array}{l}\text { Last stage, validation with } \\
\text { individuals. }\end{array}$ & $\begin{array}{l}\text { No } \\
\text { viduals. }\end{array}$ & $\begin{array}{l}\text { Approved LO, yet needs more contact } \\
\text { with computer science material to adapt } \\
\text { to technologies }\end{array}$ \\
\hline $\begin{array}{l}\text { M (blind) } \\
\text { Last stage, validation with indi- }\end{array}$ & $\begin{array}{l}\text { Accessible. Approved LO. Played the } \\
\text { game again to improve performance. }\end{array}$ \\
\hline
\end{tabular}


This validation with users was essential for the adaptation of LO. Without the blind and visual impairment subjects, we would have not sufficient knowledge to apply the changes. Practical studies on accessibility are not enough unless there are users who use the adapted resources in their daytime tasks. Learning about screen readers and using screen readers are very different actions. The research reported here has shown to us that developers, besides having to know about resources and languages, also need to know the target audience for which the LO is intended. Teachers that create educational material, in addition to knowing the content and features that will be used in the class, also need to know potentials and limitations of the students in its classes.

The interactions with the subjects and the LO are not reported in this article, however, this information is available in the original document (Dias, 2010). These interactions reaffirm the effectiveness of the methodology used in the creation and adaptation of accessible LO.

All four stages of the adaptation methodology can be synthesized in a workflow as shown in Figure 2. The stages are continuous and the validation of the adapted LO by testing subjects is a permanent task along the all stages. This development and re-adaptation process can be employed either for the construction of LO or the development of educational software.

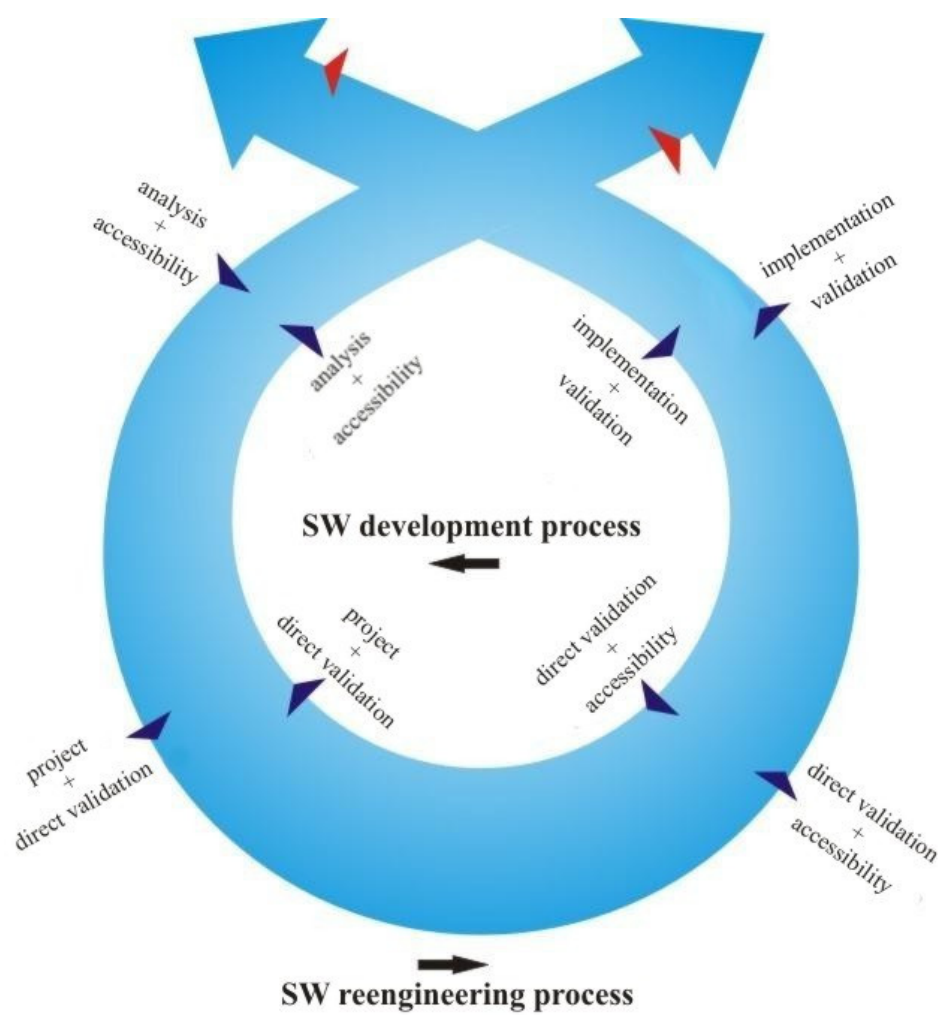

Figure 2: Software development workflow.

\section{Final Remarks}

We believe that the results achieved with this research are important for the field of special educational under an inclusive perspective. Such relevance is reaffirmed when we take in account that teachers are becoming promoters of their own material, and that students with special educative needs not only wish diversified material, but also require inclusive material. Indeed, the 
process of the adaptation of classroom material can be considered constant, as it has been identified during interviews with teachers for this research.

With the intention of assisting the development of LOs, we set the goal to create a methodology that can provide the adaptation of an existing LO into one Accessible LO. To test the methodology we applied it to the Quincas Shop LO, developed by the UNIFACS Salvador team. After the adaptation process the LO was used in two inclusive schools, where it was validated by blind and low vision subjects. The validation of the proposed methodology confirmed its feasibility and allowed us to infer the impact that the methodology can cause in the educational process.

From this experience, we came to believe that these results will be useful to the development and adaptation of Learning Objects for students with special needs, particularly for the blind and low vision students. Other kinds of special needs are being considered in future works, to extend the applicability of the methodology.

\section{References}

Behar, P., Passerino, L., Dias, C., Frozi, A. P., \& Silva, K. K. (2009). Um Estudo sobre requisitos pedagógicos para objetos de aprendizagem multi-plataforma. IFIP World Conference on Computer in Education 2009. Bento Gonçalves, July.

Brazil. (1999). Presidência da Republica. Casa. Decreto Lei 3.298. Retrieved December 4th 1999 from https://www.planalto.gov.br/ccivil/decreto/d3298.htm

Brazilian Ministry of Education. (2009). Ministerio da Educacao. Banco Internacional de Objetos Educacionais. [International Database of Educational Objects]. Brasilia, DF: MEC/SEESP, 2009.

Borges, A. (2006). Projeto Dosvox. [Dosvox Project] Retrieved: may 2008 from http://intervox.nce.ufrj.br/dosvox

Chilkofsky, E. J., \& Cross, J. H. (1990). Reverse engineering and design recovery: A taxonomy. IEEE Software, 7(1),13-18.

Coleman, D. (1996). Desenvolvimento orientado a objetos: o método fusion. [Object-oriented development: the fusion method (1994)] Rio de Janeiro: Editora Campus.

Coll, C. (1996). Psicologia e Currículo. Uma aproximação psicopedagógica na elaboração do currículo escolar. [Psicología y Curriculum. Una forma de psico-pedagogía del desarrollo curricular. Paidos Iberica, Ediciones S. A. (15 Mar 1991)] Sao Paulo: Atica.

Dias, C. (2003). Usabilidade na Web: Criando portais acessiveis. Alta Books.

Dias, C. (2010). De olho na tela: requisitos de acessibilidade em objetos de aprendizagem para alunos cegos e com limitação visual. [Keeping an Eye on the Screen: Application Accessibility for Learning Objects for Blind and Limited Vision Students]. Dissertação de Mestrado, Universidade Federal do Rio Grande do Sul. March.

Dias, C. \& Passerino, L. M. (2008). Objetos de Aprendizagem e Acessibilidade: um estudo sobre objetos acessíveis. XIX Simpósio Brasileiro em Informática na Educação. Fortaleza - November.

Granollers, T. (2004). Una metodologia que integra la ingenieria del software, la interacción personaordenador y la accesibilidad en el contexto de equipos de desarrollo multidisciplinares. Tesis de doctorado, Universidad de Lleida, July.

Mittler P. (2003). Educação Inclusiva: contextos sociais. [Working Towards Inclusive Education: Social Contexts. David Fulton Publishers, Jan 2001] Porto Alegre: ArtMed.

ORCA. (2009). Orca Screen Reader. Retrieved July 24th 2009 from http://live.gnome.org/Orca 
RENAPI. (2009). Rede Nacional de Pesquisa e Inovação em Tecnologias Digitais. [National Web of Research and Digital Technology Innovation]. Retrieved March 10th 2009 from http://bento.ifrs.edu.br/acessibilidade/index.php

RIVED/SEED. (2008). Rede Interativa Virtual de Educação [Interactive Web of Virtual Education]. Retrieved November 12th 2008 from http://www.rived.mec.gov.br/

Santanchè, A. (2008). Projeto Jogos e Objetos de Aprendizagem. [Project Games and LO]. Retrieved August 2008 from http://logames.sourceforge.net/

SEESP. (2003). Ministerio da Educacao. Diretrizes Nacionais para a Educação Especial na Educação Básica. Brasilia, DF: MEC/SEESP, 2003.

Sonza, A. P. (2008). Ambientes Virtuais Acessíveis sob a perspectiva de Usuário com Limitação. Tese Doutorado [Virtual Environments Accessible from the perspective of User with Limitation. $\mathrm{PhD}$ thesis]. Universidade Federal do Rio Grande do Sul, Programa de Pós-Graduação em Educação, Porto Alegre.

Sun. (2009a). Accessibility. Retrieved July 16th 2009 from http://www.sun.com/accessibility

Sun. (2009b). Developing Accessible JFC Applications - Test Cases. Retrieved July 16th 2009 from http://www.sun.com/accessibility/docs/dev_access_apps.jsp\#4

Sun. (2009c). Java Accessibility Quick Tips - Ensuring and Verifying Basic Application Accessibility. Retrieved July 16th 2009 from http://www.sun.com/accessibility/docs/java_access tips.jsp

Takahashi, T. (1990) Programação Orientada a Objetos [Object-Oriented Programming]. Escola de Computação, São Paulo.

Viccari, R., Gluz, J. C., Passerino, L. M., Santos, E., Primo, T., Rossi, L., Bordignon, A., Behar, P., Filho, R., \& Roesler, V. (2010). The OBAA Proposal for Learning Objects Supported by Agents. Proceedings of MASEIE Workshop - AAMAS 2010. Toronto, Canada.

W3C. (2008). Web Accessibility Initiative. Retrieved April 6th 2008 from http://www.w3.org/WAI

Wiley, D. A. (2001). Connecting learning objects to instructional theory: A definition, a metaphor and a taxonomy. In D. Wiley, D. (Ed.), The instructional use of learning objects. Retrieved May 2008 from http://www.reusability.org/read/chapters/wiley.doc

Wiley, D. A., \& Nelson, L. M. (1998). The fundamental object. Retrieved August 20th 2008 from http://wiley.ed.usu.edu/docs/fundamental.html

\section{Biographies}

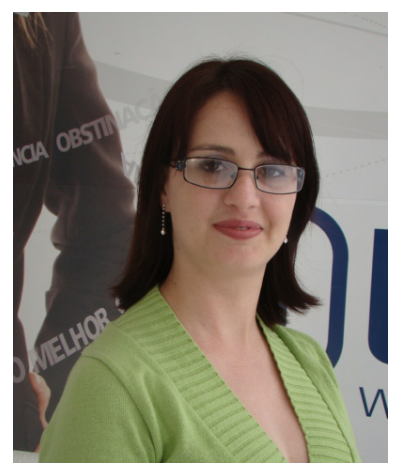

Cristiani de Oliveira Dias, Master in Education by the Federal University of Rio Grande do Sul (UFRGS) in Brazil, Specialist in Informatics in Education by the Luteran University of Brazil and Bachelor of Informatics by the Universidade da Região da Campanha. Presently as PhD in Computer Education at Federal University of Rio Grande do Sul (UFRGS), with a line of research in Informatics in Special Education and groups of development of Accessible Learning Objects along with the implementation of supporting software for Distance Learning that focuses on the blind and limited eyesight.

Mail: cristianideoliveiradias@gmail.com

Address: Av. Paulo Gama, 110, PGIE- room 340, CEP 90046-900 - Porto Alegre-RS Brazil Phone/FAX: +55 -51 - 33083070 


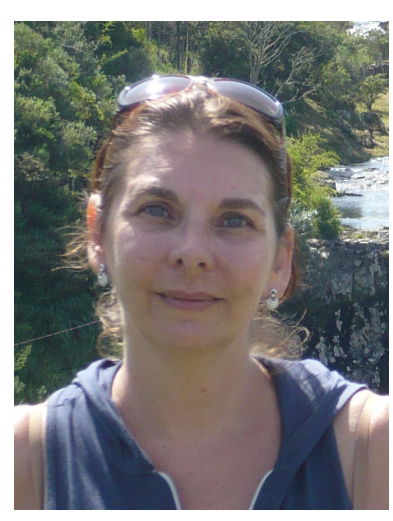

Liliana M. Passerino received her $\mathrm{PhD}$ in Computer Education in 2005 from Federal University of Rio Grande do Sul (UFRGS), Brazil and MSc in Computer Science from UFRGS in 1992. Currently is a professor and researcher at the Federal University of Rio Grande do Sul (UFRGS), Rio Grande do Sul, Brazil, working in Post-Graduate Education and Computer Education. Productivity Fellow CNPq (National Research Council in Brazil) conducting his research on the theme of inclusion, disability and technology. Currently his main research is related to the development of educational technologies and methodologies in the field of visual impairment and pervasive developmental disorders, with special focus on augmentative and alternative communication.

Mail: 1iliana@cinted.ufrgs.br

Address: Av. Paulo Gama, 110, PGIE- room 340, CEP 90046-900 - Porto Alegre-RS Brazil Phone/FAX: +55 -51 - 33083070

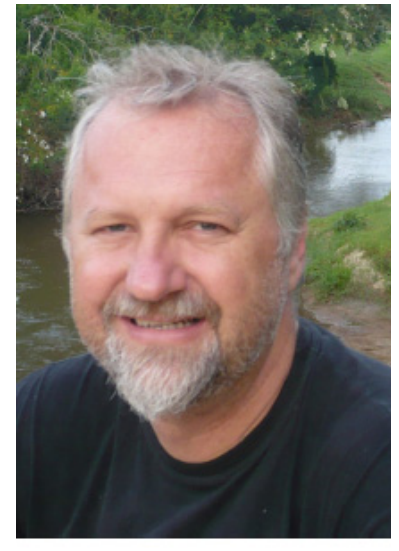

João Carlos Gluz PhD in Computer Science at Federal University of Rio Grande Sul, Brazil. Associate Professor at Vale do Rio dos Sinos University (UNISINOS), Brazil. 